\title{
Policy of Attention to the User of Drugs in Brazil
}

\author{
Fabiola Xavier Leal \\ Social Work Departament \\ Maria Lúcia Teixeira Garcia \\ Social Work Departament \\ Coordinator of the Master Degree in Social Politics \\ Researcher of the CNPq \\ E-mail: lucia-garcia@uol.com.br
}

This research is supported by CNPq.

\begin{abstract}
The aim of this article is to reflect on Anti-Drug City Councils (COMADs) having as the main idea the proposal done by the Brazilian Anti-Drug Policy. In this way, it starts from the conception of the contradictory space that covers the councils of policy and, in specific, as the creation of the Councils in $10 \%$ of the Brazilian cities that had not resulted in its effective implementation. For this analysis it was used a data base supplied by the Anti-Drug National Department (Senad) and a research applied to the State and City Councils (by E-mail) using a questionnaire developed for this end. Making an analysis of this policy, it is identified that the situation of the COMADs shows that Brazil does not practice it, what corresponds to a situation in which its proposal in federal and state level depends on specific decisions taken in the city sphere. And the city decisions the COMADs creation do not come followed by conditions for its full effectiveness.
\end{abstract}

Keywords: Public Policy, Drugs, Anti-Drugs City Council, Social Control

\section{Background}

Brazil is a developing country with an estimated population of 189,399, 727 inhabitants (Brazil, 2007). Throughout the last century the country became the largest economy in Latin America. Conversely, it also became the most socially unjust, exhibiting a perverse concentration of income: $10 \%$ of the population possesses $47 \%$ of the national income, while $50 \%$ of the population possesses a mere $13 \%$ of the total (Sader, 2003). According to statistics provided by UNICEF, $10 \%$ of the Brazilian population lives on less than $\$ 1$ a day.

The aim of this article is to reflect on the Anti- Drug City Councils (COMADs) having as the main idea the proposal done by the Brazilian Anti-Drug Policy. In this way, it is necessary to start questioning the issue and how the historical and socially constructed conceptions will shape the proposals of the policy of confrontation face to the growth of the offer and the demand.

The use of drugs appears as a complex phenomenon of the life in society that involves political, economical, social and cultural issues (Bucher, Oliveira, 1994), being seen under different prisms: the relation modified between man and drug; the economic aspect of the market, the social impact generated by its increasing consumption, the historical, social and legal aspects involved in this process. Such debates receive contours that vary between position (and politics) sometimes of repressive character (Dry Law, prohibition of the marijuana use, for example) sometimes of flexible character (marijuana use for therapeutical ends, or all the debate around the decriminalization or release of cannabis) that vary as the historical moment.

When considering the estimates that point that $11.2 \%$ of the adult Brazilian population still have alcoholic addiction and, $6 \%$ of the population present serious psychiatric upheavals resulting of the alcohol use and other drugs (Brazil, 2005), we verify that the question of the improper use of alcohol and drugs in general comes being incorporated to the Brazilian politics agenda mainly since the $80 \mathrm{~s}$.

The dimension of the kinds of problems related to drug abuse can vary in relation to the time, country or in its different impacts on the community. Analyzing the public policy for the improper use of drugs, it is observed that these oscillate between measures of control on the behavior of the drug consumer and measures of control on the access of these drugs (Garcia, Leal, Abreu, 2008). On the other hand, the measures in relation to the illicit drugs center on the 
reduction of the offer through the combat to the drug traffic and the money laundering (Ribeiro, 2000). Also there are a broad range of commercial interests and different actors, as the governments (in the three instances), the media, the Non-Governmental Organizations (NGOs), the public opinion and the related activities, the users of drug, the scientific community, among others (Babor, Caetano, Casswell, 2003).

In general, the annual revenue that comes from the illegal industry of the drugs reaches US\$ 400 billions, or equivalent $8 \%$ of the total international trade. This industry brought some power to the organized criminals, it corrupted governments in all levels, eroded the internal security, stimulated violence and distorted the moral values and, also, of the economic markets. These are the consequences that do not come from the use of drug itself but of decades of inefficient policies on the sphere of reduction of offers and on the sphere of reduction of demand (Ribeiro, 2000).

To think about this issue and its implications requires studying the context that it inserts itself. It is a basic thematic of the Social Policy, for characterizing itself as expression of the social matter (4), consisting in a social reality that can be studied scientifically. The improper use of drugs is also fruit of the expressions that the social matter adopts in the current moment of the capitalist society. The social matter inserts in the context of the impoverishment of the labor class with the consolidation and expansion of the capitalism since the beginning of the XIX century, as well as the picture of fight and the acknowledgment of the social rights and the corresponding public policy, beyond the space of the organizations and movements for social citizenship (Gorgulho, 2006). On the other hand, the historical context of formation of the Brazilian society was established with a logic based on assets, with the Latin America appropriation and agrarian concentration and not for the formation of the public thing (Ribeiro, 2000).

All this set of factors is added to the conceptions that are produced from the issue of drugs, conceptions these that will modulate the proposed actions. In the case of the policy of attention to the use of drugs it is observed that the speeches concentrate between two polar areas: one of moralist tone and the other of scientific tone. The moralist tone includes the phenomenon in an anti-drug crusade, which is, in an ideological-moral articulation that spreads out drugs as dangerous and extremely destructive substances. The prohibition, the natural way of fighting against it, is strengthened by the policy, the media, religious and health authorities that tend to describe drugs in its ideological speeches in an extremist and moralist tone.

The social matter can be characterized by a concern as to the capacity to keep the cohesion in a society. The rupture threat is presented by groups whose existence shakes the cohesion of the group (Castel, 1998). In this way, we can size the shake caused by the improper use of drugs and its implications into the contemporary society.

A second scientific speech presents, in general, an epidemiologic tone. Here is described the way of behavior of usage, abuse and dependence of drugs and related damages. Attention still for methodological problems of the subject, considering the definition of categories and processes of analysis. In general, the subject drugs is tense and contradictory so that it can define an approach, involving the segments of the oppressed class of the society, racism, organized crime, social banditry (Ribeiro, 2000), public policy (Bucher, Oliveira, 1994), until the individual that consumes drug (WHO, 2001). Therefore, more journalists make the stories with the view of their formation; psychologists determine the approach from the illness of the individual; the morality of the common sense determines a look deceived by prejudice and the criminalization that comes from this morality feeds a technical dominant analysis. In the dialectics relation between man and drugs, the contradictions are so diverse and current, beyond being used to the coexistence in the illicit one, that they end for losing the dimension of its gravity (Procópio, 2000).

The anti-drug policies implemented in many countries have a regulation character (according to the classification of Frey, 2000), that is, work with orders and prohibitions and decrees. The referred effects to the costs and benefits are not determined beforehand, they depend on the concrete configuration of each policy. Costs and benefits can be distributed in an equal way and balanced between groups and sectors of the society, in a similar way as well as they can take care of the particular and restricted interests. The processes of conflict, of consensus and coalition can be modified according to the specific configurations of the policy.

This regulation process also comprehends the concept of social control, which passes through the relation State $\mathrm{x}$ Society. This relation is in the base of the understanding of the social policy and the citizenship, where the society is the main opposite of the State, but also its main term of complementation. This relation is passed by the antagonism and reciprocity that put into motion the scene of history. And facing these conflicts there are, in the relation of the State with the society, two ways of intervention: the pure and simple coercion, typical of the restricted State and the politics as possibility of solve conflicts by consensus (even so it has the coercion as possibility), where inserts the contradiction (Pereira, 2002).

When social control in Brazil is debated; it is brought to the scene the councils that currently possess a different configuration of its origins. Starting from the labor councils (that are organized ways of democratic participation that look for breaking with the centrifugal power, which tries to restrict the social fights and class conflicts in the productive unit - plant or country property), there is in its interior a historical fight that gained force in the XIX century, when the 
workers had started to organize themselves in order to have a policy of public, universal, free and secular education, labor laws respected and dignity, as the example of the Commune of Paris. For a long time, this subject was debated in the left field and particularly by Karl Marx (Leher, 2004). It is a subject that Marx theorized in an outline of the fight for a society without exploitation. Marx and Engels (2004) affirmed that the form of participation praised by liberals did not assure the democracy. Gramsci (2002) also theorized on the relation between State X Councils. He said that to construct a democratic State, it must have as basis the councils of workers in the plants, in the field etc. Thus, these workers could think different ways of organizing production in the plants, school and communitarian work, cultural activity, health etc. In the strategy of councils, Gramsci (2002) places in action a new political practice. This author does not make opposition between council and party, between base movement and political direction (Leher, 2004).

In this historical process of evolution of the councils, what we can perceive is that the appropriation made by the capitalism and the neoliberal thought attributed to the council a completely different sense of that one proposed by fractions of the left. Whereas for the left the councils aim to assure the self-organization and the self-determination of workers, for the liberal ones, the councils are instruments to extend the privatization of the State, as the logic of the capital. They are ways of containment of the contradictions and the class conflicts on behalf of established order (Leher, 2004). In this sense, many governments work with councils as a way of organize workers, entrepreneurs and the government in favor of the peace of the capital, such as in fascist Italy in 1930, Hitler in Germany, Franco in Spain, Getúlio Vargas in Brazil (decades of 30/40). It was done to diminish the autonomy and the critics of the left labor unions movements. It was about the autonomy end the critics to the labor union movement of left. In this way, the councils appear as a way of "social consensus" (Leher, 2004).

The councils appeared in Brazil in the 80s and 90s differentiate itself of the previous ones, for constituting in locus privileged of the processing of the mechanism of the decentralization, which one would become possible to allow the society the control on its proper reproduction and on official decisions (Pereira, 2002). Carvalho (1995), referring to experiences in the area of health, says that there is nothing in the history of the Brazilian State that if resembles the councils nowadays, and for its social representation or for the wide range of legal power invested in them.

According to Leher (2004), the subject "council" is central in any strategic analysis of the future, because it mentions the way of participation of the society in the social control of the politics implemented by the State. The participation of the councils in the processes of formation of politics (policy formation) is considered important, since they enjoy of high visibility and its work seems relatively integrated to the knowledge and expectations of the agents, especially the government. However, they can still stop at some limits that still exists, and that, in some way, reduce its capacity of sharing and influencing in some governmental decisions (Draibe, 1998).

Considering these aspects, the political component an of the councils is very important for the process that decides about public policy This politic component involves correlation of forces, articulacy with segments of the civil society, principles of democracy and transparency, with technical capacity and legal ability that the council members have in guarantee spaces of participation and control of the public thing; capacity of the council members, in the use of its legal attributions, to overcome typical red tape and legalist trends (Rizotti, Lopes, Santos, 1999).

\section{The Drugs problem in Brazil}

As for the current issue of drugs, all this dynamics inscribes itself in the adoption of legislations for the majority of countries that follow the agreements of Single Convention on Narcotics Drugs of 1961 and the Convention on Psychotropic Substances of 1971. These international agreements, promulgated under strong American pressure, approach the issue of drugs from a limited perspective, introducing classifications of strict pharmacologic nature and giving almost no attention to the factors of social or cultural order. As much in the international treaties as in the national legislation and politics that come from them, it doesn't recognize the problems pointed out for the use of psychoactive as cultural production, ignoring deep heterogeneities in the consumption ways, reasons, beliefs, values, rites, styles of life and visions of world that support it (MacRae, 2000).

The historical absence of politics that promote the social protection, health and treatment of the people who use, abuse or are dependents of drugs in Brazil reproduce a scenery of focal politics, organized in an excluding logic. In this context, it is identified the shaping of a policy in which the politic guidelines and agendas evidence contradictions: a) association of the alcohol use and other drugs to violence, in a direct association; $b$ ) in spite of deny, politics end adding stereotypes to users, reaffirming its social segregation; c) absence of social and economic analyses that point out with respect to the inclusion of the traffic as an alternative of work and generation of income for poor populations, in special to the use of young workmanship in this market; d) No inclusion of the user of drugs in the composition of councils, reproducing the illegality of the as a possible obstruction to its social participation in an organized way; e) the legal treatment and in an equal way to every member of the "organizational chain of the world of the drugs" is different in terms of penalization and alternatives of intervention.

For Ribeiro(2000), all these issues have direct relation with the existing economical and political processes, mainly in 
the Latin American countries and with desperate options of entrance in the capitalist market, even if for the almost exclusive way of "illegal" and "illicit" businesses. According to him, there is a set of prejudiced, ethnocentric and ideological explanations that hide such consequences and are presented in an official way with international endorsement, involving National Congresses, The Army and World- Wide Organisms. Although of a speech centered in a sanitary concern of drug trafficking eradication, the interests of the U.S.A. with the ones of the internal elites match, what practically can be translated contents that also can disclose an economic dispute in direction of the illicit business (Ribeiro, 2000).

From this historical description, it realizes that drug policies can be understood from different points of view: first, it believes that the "problem" will disappear when eliminating the use. And, in this case, the policy supports itself on the judicial and police powers, it would be a repressive reply; second it believes that the "problem" exists due to little flexibility of the society and the policy would be the promotion of the self management on the use and organization of a social system that compensated the contingent damages, in a reply of legalization; then it assumes that the "problem" does not have definitive solution but that there is the necessity of support to a range of social programs. In this case, the policy periodically reorganizes itself because of new drugs, new habits of consumption and crises in the social relations that disturb the subjectivity of the individual, in a pragmatic reply (Acserald, 2005).

Thus, to think the Policies of Attention to the Improper Use of drugs, it is necessary to question itself after all what are the councils - they are structures that widen the democratic space or are agencies submitted to the logic of the State; which the paper of these spaces inside of these policies; and, above all the optics of the social control that establishes itself from these instances, among others aspects. When considering the councils in the area of drugs as one of the spaces to bring into effect the social control, in a perspective of the society as public actor (that it establishes a relation of accompaniment of the State in its actions directed toward the public) it is to consider the daily process of taking public decision as spaces of greaten democratic reach. This requires that it carries out urgently a balance, pointing out difficulties for full accomplishment of actions.

\section{The Anti-drugs councils in Brazil}

The anti-drugs councils had appeared with the implementation of the National System of Prevention, Control and Repression of Narcotics, in the 80s. They were denominated Councils of Narcotics in federal, state and municipal instances - CONFEN, CONENs and COMENs, respectively. Although they had been created in the 80s, the anti-drugs councils had not been created from pressures of the civil society or from the fight of social movements, as observed in other existing councils in Brazil. However, these spaces also are influenced by the scenery of the neoliberal hegemony, with the reduction of the social rights, unemployment and precariousness of work, dismounting of the public welfare and trashing of the social politics, in a way to debilitate the collective representation and social control over the State, achievement of the CF of 1988

The creation of these councils identifies a phase of drugs policy in Brazil. Nevertheless, in fact the innovative action of these spaces was limited to punctual interferences: as the evaluation of prevention campaigns released in the media, in an attempt to rethink the repressive content of the same ones; it implemented a debate that resulted in the legalization of Santo Daime (5); creation of the communal council in the CONEN-RJ, with representation of many sectors of the society (NGOs, institutions in the area of drugs, universities, entities of students etc). In this council it was criticized the repressive policy and the criminalization of the user was considered a problem to be faced; implantation of nucleus of studies and research in primary attention and treatment of drug dependence in many states of Brazil, linked to state universities (NEPAD/UERJ, PROAD/SP, CETAD/BA etc). From these nucleus, some questions had been debated, for example, the prevention concept (to avoid that something happens) is substituted by the concept of primary attention (a set of measures that promotes a critical decision, basic instrument in the educators qualification courses) (Acserald, 2005).

In 1998, the government extinguished the CONFEN and, in its place, instituted the CONAD. Some changes had occurred in this transition: first the association (it left the Ministry of Justice to associate the Cabinet of Institutional Security) and denomination (of Federal Council of Narcotics for e National Anti-drug Council) and, second, as the composition. However, the new members are governmental representatives and it is still verified negation of the organized civil society participation, without the governmental indication (Brazil, 1998). Subsequently, the President modified this composition with the Decree $n^{\circ} 4,513$ of 13/12/2002 and granted to the president of the council the power to invite a representative of the State Council of Narcotics or Anti-drugs to compose the CONAD. The choice of this representative happens by means of process of indication and approval of the presidents of the state councils (Brazil, 2002).

In Brazil, there are 26 Anti-drug State Councils, among them Amapa the single state that does not possess a Council in state or city levels. As the association of these Councils, it varies as the state (in some to the Health Department; in other to Public Security and social defense, and, still, to the Justice State Department) (Brazil, 2005). It shows us that each state fits its Council in the Department that evaluates to be the responsible one for dealing with the drug 
phenomenon. These associations translate with them the focus given to the prevention and repression and also a polarization of the structures that compose the Anti-drugs System, consequence of fragmented measures and detached from the other actions of this issue confrontation.

In the Database of the SENAD it has 548 City Councils, but an analysis of the same one demonstrates that some Councils are listed in duplicity and some are State Councils. Therefore, the total of Councils registered in this data base is of 540. Around 10\% of Brazilian cities possess COMADs, but great parts of these are inactive (Garcia, Leal, Abreu, 2008). The expectation of the National Anti-drugs Department was to implant the COMADs in $80 \%$ of the Brazilian cities up to 2002 (Salgado, 2002). Thus, the data points that the same 10\% existing in 2002 remain in 2006.

An analysis of these COMADs points that the majority meets inactive or was only created but not implemented. The reality points for the non accomplishment of this privileged space of involvement of the local community in the formulation, debate and implementation of drug problematic strategies of confrontation.

It is up to the Councils to accomplish the City Anti-drug Policies and to each member the accompaniment and control of the full development of the referring actions to the drugs demand reduction close to the several community sectors (Brazil, 2002). It is still up to the Councils acting as coordinators of activities of all the institutions and entities whose activities are related to this thematic. Its action requires being aware of the communitarian movements, the organized entities, as well as the representations of the existing institutions in the scope of the performance of each Council and ready to cooperate with the anti-drugs cause (Brazil, 2002).

With the ability of formulate the city anti-drug policy and follow its implementation, the current situation points the space empty. Such fact, paraphrasing Gramsci: the analysis points to a "pessimism of the reason" but contradictorily it reaffirms the necessity to assume optimism in our actions for the accomplishment of the Anti-drugs City Councils.

\section{Conclusion}

The social control subject is central in any strategic analysis of the future, because it is related to the tense relation between State and society. Concentrating the debate around the participation in the interior of the Councils that manage policies of many kinds (health, school, communitarian, black, woman etc), the issue of the analysis of these spaces as contradictory spaces and fight only recently got into the agenda of Brazilian researchers (end of 80s).

As a space of democracy construction, the Anti-drug Council is requiring a balance sheet makes possible to uncover the obstructions for its accomplishment. So, it is as part of the State, but independent of the government, that the councils will be able to find its renewed role in the democratic reform of the State. Although the mere existence of councils in $10 \%$ of the Brazilian cities already has a general an cultural effect, it is in the daily decision process that these agencies can find greater democratic reach. As important ways of collective participation and creation of new politics relations between governments and citizens, the anti-drug councils potentially bring the possibility as much of creation of spaces of public debates as of establishment of negotiation mechanisms and agreement to socialize the governmental actions and deliberations. On the other hand, the reality points that the anti-drug councils are being created and not implemented in the city sphere, generating an emptiness of this space as space of fight and deliberation of the city anti-drug policy.

Making an analysis of this politics, it is identified that the situation of the COMADs in Brazil explicit the non execution of the formulated policy, that corresponds to a situation in which the proposed policy in federal and state levels depends on specific decisions taken by the city sphere. And these city decisions of the COMADs creation do not come followed of conditions for its full accomplishment.

Thus, the current moment is of reflection and action; reflection on the way to understand these spaces, their potentialities and limits; action to call up the cities and the National and State Anti-drug Council to put into debate the current scenery and the necessity of accomplishment of strategies for the COMADs empowerment.

\section{Acknowledgements}

These reflections take part on the Dissertation Project about the Anti-Drug Councils in Brazil from the from the Master Degree in Social Politics of Federal University of Espírito Santo - Brazil. The aim here is excite questions and provide reflections on Anti-Drug Policy. Research financed by FUNCITEC.

\section{References}

Acserald, G. (2005). Politics of drugs and culture of resistance. June from http://www.fsmt.org.co/aa/ing-upload.

Babor, T. F.; Caetano, R. \& Casswell, S. (2003). Alcohol: no ordinary commodity research and public policy. Oxford Press.

Brazil. (1998). Provisional measure 1689-6. Official diary of Federative Republic of Brazil. Brasília: Autor.

Brazsil. National System Antidrugs. August, 2002 from http://www.obid.senad.govr.br. 
Brazil. (2005). Cabinet of institucional security. National Politics Antidrugs. Brasília: SENAD.

Brazil. (2007). Instituto Brasileiro de Geografia e Estatística. População estimada em 2007. Disponível: www.ibge.gov.br.

Bucher, R. \& Oliveira, S. R. M. (1994). The speech of the combat to the drugs and its ideologies. Journal Public Health, 28, 137-145.

Carvalho, A. I de. (1995). Advice of health in Brazil: participation citizen and social control. Rio de Janeiro: FASE/IBAM.

Castel, R. (1998). The Metamorphoses of the Social matter: a chronicle of the wage. Petrópolis: Vozes.

Draibe, S. (1998). The new institucionality of the Brazilian System of Social Politics: the national council sectorial politics. São Paulo: NEPP/Unicamp.

Frey, K. (2000). The new institutionalism of the Brazilian System of Social Politics: the council of national expression. Planning and Public Politics, 21, 211-259.

Garcia, MLT, Leal, FX, Abreu, CC. (2008). Brazil's anti-drugs policies: old dilemmas. Psicol. Soc. [online], 20,2, pp. 267-276.

Gorgulho, M, Ros, V. (2006). Alcohol and harm reduction in Brazil. International journal of drug policy, 17, 4, $350-357$.

Grasmci, A. (2002). Notebooks of the jail: Maquiavel. Notes on the state and the politics. (2 rd ed). Rio de Janeiro: Civilização Brasileira.

Marx, K, Engels, F. (2004). The communist manifest (8rd ed.). United Kingdom: Penguin.

Leher, R. (2004). The national Council of education in the neoliberal context: Participation and manufactured consensus. In Scheinvar, E; Algebaile, E. (Eds). Participativos councils and school (pp 25-39). Rio de Janeiro: DP\&A.

Mac Rae, E. (2000). Anthropology: social, cultural and ritualísticos aspects. In Seibel, S.D.; Toscano Júnior, A. (Eds). Dependence of drug (pp 25-46). São Paulo: Atheneu.

Pereira, P. A. P. (2002). Social politics, citizenship and neoliberalism: reflection on the Brazilian experience. In Carvalho, D. B. B; Sousa, N. H. B de; Demo, P. (Eds). New paradigms of the social politics (pp 253-273). Brasília.

Procópio, A. (2000). The drug trafficking in the agricultural space of the Amazônia. In Ribeiro, A. M. M; Iulianelli, J. A.S. (Eds). Drug trafficking and violence in the field (pp 15-54). Rio de Janeiro: DP\&A.

Ribeiro, A. M. M. (2000). Sociology of the drug trafficking in Latin America and the camponesa question. In Ribeiro, A. M. M; Iulianelli, J.A.S. (Eds). Drug trafficking and violence in the field (pp35-60). Rio de Janeiro: DP\&A.

Rizotti, M. L. A, Lopes, M. H. C \& Santos, J. F. dos. (1999). City councils of social Assistance: a study of its abilities and compositions. Social service in Magazine, 2, 1. November 2005 from http://www.ssrevista.uel.br.

Sader, E. (2003). The revenge of history. São Paulo: Boitempo.

World health organization. Mental Health Policy Project: policy and service guidance package. December 2001 from http://www.who.int/mental_health/media/en/47.pdf.

Notes

The Daime is an extracted tea of two hallucinogen plants. These plants, of which produces the tea, are used at Daime and the Union of Vegetal Cult. They are practiced in the North (Amazonia and Acre regions), as well as in the region Center West, in the States of São Paulo and Rio de Janeiro. 